\title{
T cell-mediated immunity and tissue damage in the gut
}

THOMAS T MACDONALD, PHD, MRCPATH

TT MACDONALD. T cell-mediated immunity and tissue damage in the gut. Can J Gastroenterol 1993;7(2):87-90. The mucosal immune system is well equipped to mediate cell-mediated hypersensitivity reactions since $T$ cells and antigen presenting cells are abundant in Peyer's patches and mucosa. Activation of T cells with lectins in explants of human fetal small intestine grown in vitro rapidly induces tissue damage and thus may be a model for the cell-mediated immune reaction which is ongoing in the lamina propria in active Crohn's disease. This is evidenced by the high frequency of interleukin-2 and interferon gamma-secreting cells which are abundant in Crohn's disease but not ulcerative colitis.

Key Words: Crohn's disease, Fetus, T cells

\section{Immunité à médiation cellulaire $\mathrm{T}$ et lésion tissulaire intestinale}

RÉSUMÉ: Le système immunitaire muqueux est bien équipé pour les réactions d'hypersensibilité à médiation cellulaire. Étant donné que les cellules $T$ et les cellules porteuses d'antigènes sont abondantes dans les plaques de Peyer et la muqueuse. L'activation des cellules $T$ avec des lectines dans des explants du petit intestin de foetus humain cultivé in vitro induit rapidement une lésion tissulaire et peut servir de modèle pour la réaction immunitaire à médiation cellulaire qui affecte la lamina propria dans la maladie de Crohn active. Cela est mis en évidence par le nombre de cellules sécrétant de l'interleukine-2 et de l'interféron gamma, plus important dans la maladie de Crohn que dans la colite ulcéreuse.

Department of Paediatric Gastroenterology, St Bartholomew's Hospital, London, United Kingdom

Correspondence and reprints: Professor Thomas MacDonald, Department of Paediatric Gastroenterology, Room 41, Dominion House, 59 Bartholomew Close, St Bartholomew's Hospital, London ECIA 7BE, United Kingdom
$\mathrm{T}$ HE GASTROINTESTINAL TRACT contains most of the lymphoid tissue of the body. This occurs as discrete follicular structures in and adjacent to the mucosa (Peyer's patches, colonic lymphoid follicles, mesenteric lymph nodes, appendix), and as the lymphoid/ myeloid cells within the connective tissue matrix of the lamina propria and within the gut epithelium. Traditionally, mucosal immunology has been concerned with humoural, eg, immunoglobulin (Ig) A, responses. $\operatorname{IgA}$ is the major immunoglobulin isotype present at mucosal surfaces; it protects the mucosa from colonization and invasion of infectious agents. Its role is clearly protective and because it cannot fix complement, it plays little or no part in harmful hypersensitivity responses. In recent years, however, it has become clear that antibody-mediated and cellular hypersensitivity may play important roles in intestinal disease in humans. Space precludes inclusion of evidence for the role of $\operatorname{IgG}$ and $\operatorname{IgM}$ antibody-mediated hypersensitivity in enteropathy; readers are referred to several recent papers $(1,2)$. This article 


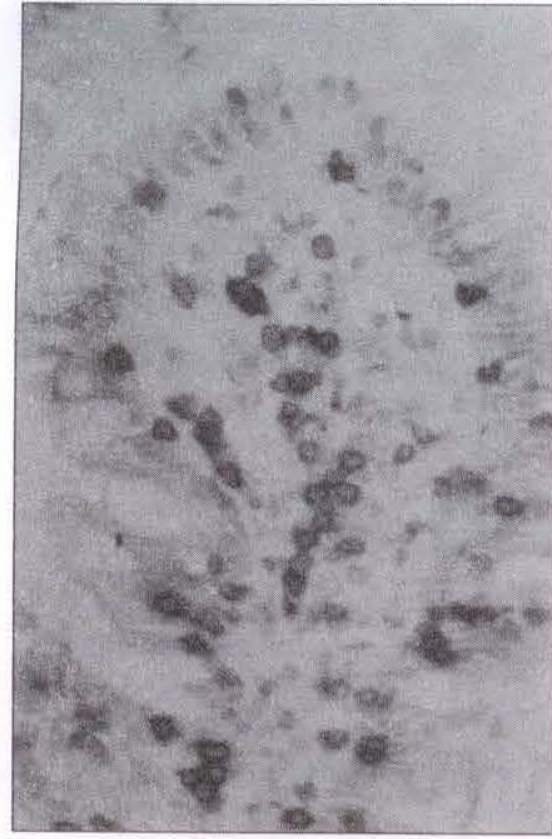

Figure 1a) $C D 3+T$ cells in normal human small intestine. Note the numerous intraepithelial and lamina propria $T$ cells (immunoperoxidase, original magnification $\times 400$ )

focuses on the recent data, mostly from the author's laboratory, on the role of $\mathrm{T}$ cells in human disease.

\section{LOCAL IMMUNITY IN THE GUT MUCOSA}

In contrast to the mucosal B cell system which develops after birth, T cells and accessory cells of the mucosa are well-developed at birth (3). There are numerous class II+ macrophages and dendritic cells in the lamina propria, and there are CD3 $+\mathrm{T}$ cells in

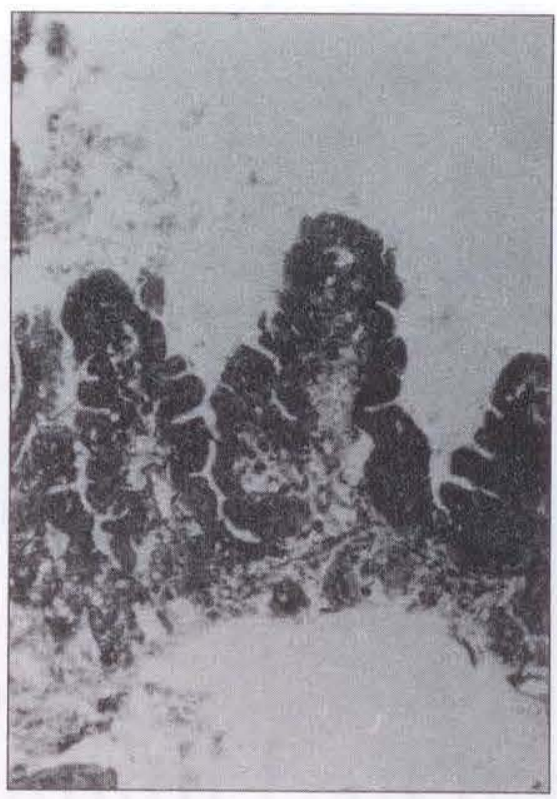

Figure 1b) HLA-DR expression in normal human small bowel. The epithelium is strongly Class $11+$ as are macrophages in the lamina propria concentrated at the tops of the villi ( $\mathrm{im}$ munoperoxidase, original magnification $\times 100$ )

the lamina propria and epithelium, albeit at reduced levels compared with postnatal bowel (3). Figure 1 shows CD3 + T cells and class II major histocompatibility complex expression in normal human mucosa. The source of mucosal $\mathrm{T}$ cells in postnatal gut is unclear. Animal experiments indicate that some intra-epithelial lymphocytes (IEL) are derived from T cells stimulated by antigen in the Peyer's patches (4). Mesenteric lymph node T blasts lodge in the gut when passively trans- ferred into recipient animals (5), but these blasts could be derived from the Peyer's patches, lamina propria, or be locally stimulated in the mesenteric node. With the large numbers of class II + accessory cells in the lamina propria adjacent to CD4+ $\mathrm{T}$ cells, antigen crossing from the gut lumen may be able to initiate a primary $\mathrm{T}$ cell response in the lamina propria; this might be of considerable importance in the immediate postnatal period when the gut epithelium may be more permeable. Not all lamina propria $\mathrm{T}$ cells are memory cells, about 30 to $40 \%$ are CD45RO- (6), and may be virgin cells derived from blood. After local stimulation in the lamina propria they may become activated, and if they leave in the efferent lymphatics to the draining mesenteric nodes, they could migrate back to the lamina propria from the blood. It should be emphasised that the above applies to $T$ cells bearing the $\alpha \beta$ TcR. T cells bearing the $\gamma \delta \mathrm{TcR}$ are very uncommon in the lamina propria (7) and make up only $10 \%$ of the epithelial T cells in humans (7).

\section{CONSEQUENCES OF T CELL ACTIVATION IN THE LAMINA PROPRIA}

There is very good evidence that the terminal maturation of $\lg \mathrm{A}$ plas. mablasts into plasma cells in the lamina propria is largely antigen-driven (8). Thus, there seems little doubt that enteric antigen can stimulate local im. munity in the lamina propria. The
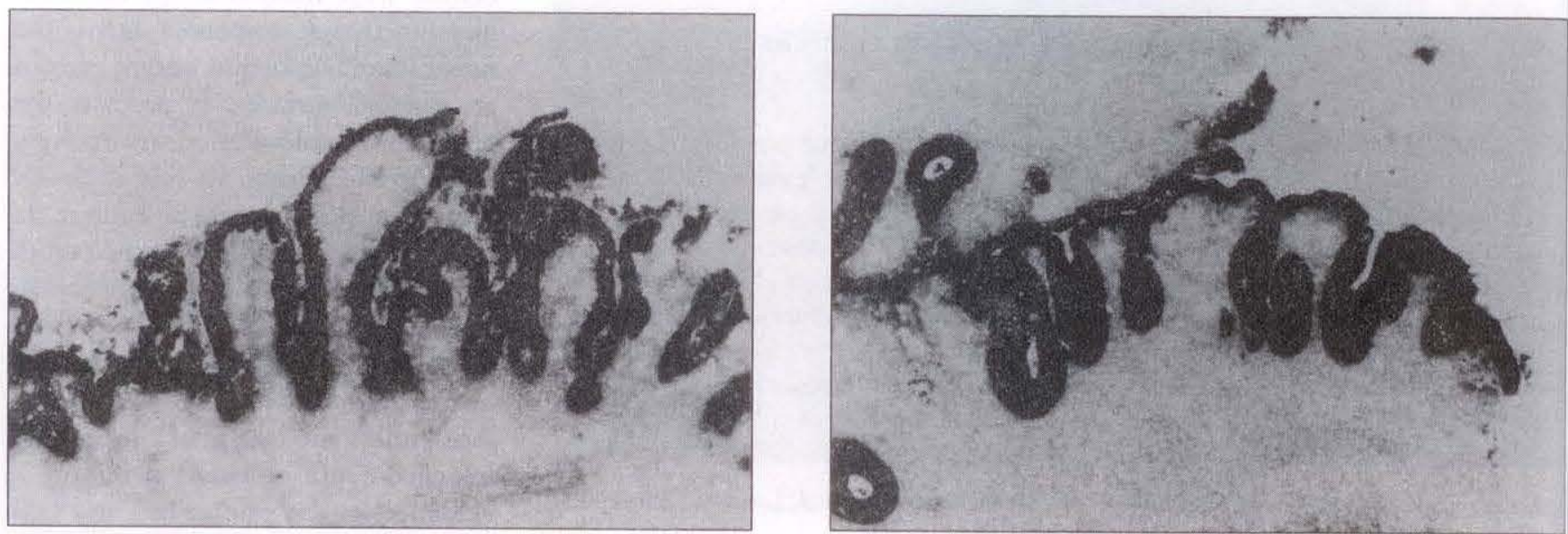

Figure 2) Left Morphology of an explant of fetal small bowel cultured for three days. Villi are tall and crypts are short. Right Morphology of explants cultured for three days with pokeweed mitogen to activate lamina propria $T$ cells. The villi have disappeared and the mucosa is flat with crypt hypertrophy (Immunoperoxidase with anti-cytokeratin, original magnification $\times 100$ ) 
situation with $\mathrm{T}$ cells is less clear. For example, after feeding mice keyhole limpet hemocyanin with cholera toxin as an adjuvant, weak antigen-specific responses can be elicited with lamina propria cells (9). There are no similar data in man. The direct evidence for $T$ cell hypersensitivity as a cause of the lesion in food-sensitive enteropathies is scant. CD25 + T cells are present in the lamina propria in celiac disease and cows' milk protein intolerance, but are also present in Crohn's disease and in some cases of intractable diarrhea (10). Their specificity is unknown. Cyclosporin A can be effective in treating some cases of intractable diarrhea in which the damaged mucosa resembles celiac disease by causing an improvement in mucosal morphology (11).

\section{IN VITRO ENTEROPATHY}

The author has recently developed a novel in vitro system to study $T$ cell hypersensitivity in human small intestine which uses mitogens to activate lamina propria CD4+ T cells directly (12). T cells migrate into fetal human intestine at about 12 to 14 weeks gestation, and increase in number thereafter (3). Explants of human fetal small bowel can also be maintained in culture for extended periods. Explants of fetal human intestine, containing $\mathrm{T}$ cells (usually from 17- to 20-week-old fetuses), were cultured with pokeweed mitogen (PWM) or monoclonal anti$\mathrm{CD} 3$ antibody to directly activate the T cells in situ. Frozen sections of explants cultured for one or three days with PWM or anti-CD3 were stained with anti-CD25 using the peroxidase method. Numerous CD25+ cells were apparent in the lamina propria of stimulated cultures, but not control cultures (12). Supernatants of cultures stimulated with PWM also contained the lymphokines interleukin (IL) -2 and interferon gamma (IFN $\gamma$ ) indicating that functional $\mathrm{T}$ cell activation had also occurred (13).

The most dramatic effects of $T$ cell activation are on explant morphology (Figure 2). After three days in culture with PWM or anti-CD3, there was partial or total villous atrophy and a profound crypt hypertrophy (12).
Using the monoclonal antibody Ki67 (which identifies all dividing human cells), it can also be demonstrated that these morphological changes are associated with a profound crypt cell hyperplasia (12). Stathmokinetic studies on microdissected tissue reveals villous atrophy, crypt hypertrophy and an increased rate of epithelial cell production (Figure 3).

$T$ cell activation in the lamina propria also leads to $\mathrm{T}$ cell proliferation and an increase in the density of lamina propria, and epithelial $\mathrm{T}$ cells (14). INFr production by the $T$ cells also increases HLA-DR expression on epithelial cells and lamina propria accessory cells (15).

\section{T CELL IMMUNITY IN OTHER ENTEROPATHIES}

Crohn's disease bears many of the stigmata of cell-mediated immunity: the lesions are granulomatous and fibrotic and the end-stage of the disease is scarring with destruction of all layers of the intestine. Consistent with this, activated $\mathrm{T}$ cells are abundant immunohistochemically in untreated Crohn's disease, but not ulcerative colitis (16).

A sensitive reverse hemolytic plaque assay to detect lymphokine secreting $T$ cells and Northern blot analysis to detect expression of lymphokine messenger RNA were used to study IFN $\gamma$ and IL-2 production in the mucosa of patients with Crohn's disease and ulcerative colitis, and in histologically normal mucosa (unpublished data). In the mucosa of most patients with ulcerative colitis and control tissue, IL-2 and IFN $\gamma$ secreting cells were present only at low levels. In contrast, in mucosa from patients with Crohn's disease, lymphokine-secreting cells were significantly raised. IFN $\gamma$ mRNA was detected by Northern blot analysis in five of six Crohn's tissues, but in only one of five ulcerative colitis samples and in none of nine samples of control mucosa. This is the first demonstration of functional $\mathrm{T}$ cell activation in the mucosa in Crohn's disease. The antigens to which these cells are responding may well be the etiological agents of the disease.

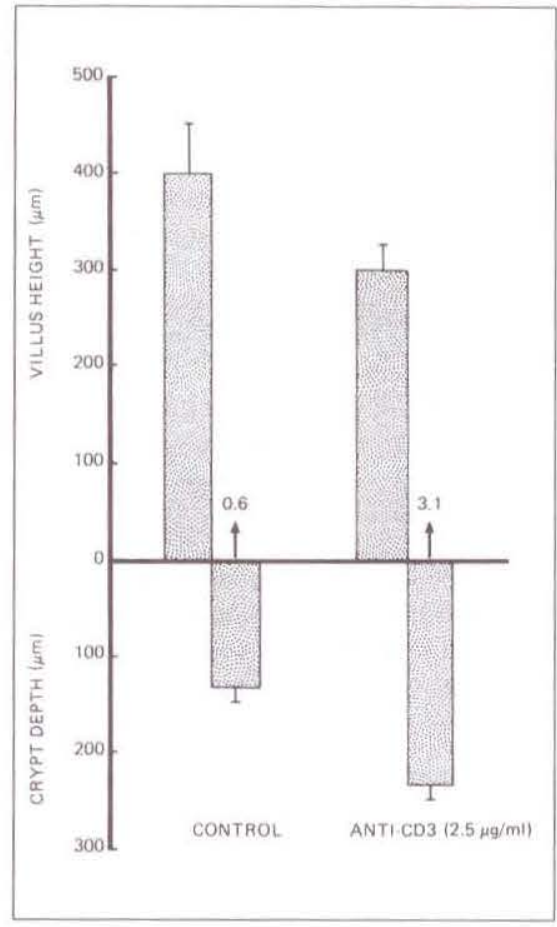

Figure 3) Epithelial cell proliferation and mucosal morphology in human fetal small intestine in which a $T$ cell-mediated immune reaction has been achieved by the addition of anti-CD3 monoclonal antibody. Three days after $T$ cell activation there is villus atrophy, crypt hypertrophy and an increase in the rate of cell production/crypt/h (arrows leaving the crypts)

ACKNOWLEDGEMENTS: Much of the work reported here was supported by The Wellcome Trust and Crohn's in Childhood Research Association.

\section{REFERENCES}

1. Brandtzaeg P. The B cell system. In: Brostoff J, Challacombe SB, eds. Food Allergy and Intolerance. London: Bailliere Tindall, 1987:118-55.

2. Brandtzaeg P, Kett K, Halstensen TS, Helgeland L. Pathogenesis of ulcerative colitis and Crohn's disease: humoral immune mechanisms. Eur J Gastroenterol Hepatol 1990;2:256-64.

3. Spencer J, MacDonald TT.

Development of the human mucosal immune system. In: MacDonald TT, ed. Ontogeny of the Intestinal Immune System. Boca Raton: CRC Press, 1990:23-50.

4. Guy-Grand D, Griscelli C, Vassalli P. The mouse gut $T$ lymphocyte, a novel type of T cell. Nature origin and traffic in mice in normal and 
graft-versus-host conditions. J Exp Med 1978;148:1661-77.

5. Rose ML, Parrott DMV, Bruce RG. Migration of lymphoblasts to the small intestine I. Effect of Trichinella spiralis infection on the migration of mesenteric lymphoblasts in syngeneic mice. Immunology 1976;31:723-30.

6. Halstensen TS, Scott H, Brandtzaeg P. Human CD8 + intraepithelial T lymphocytes are mainly CD45RA-RB+ and show increased co-expression of CD45RO in celiac disease. European J Immunol 1990;20:1825-30.

7. Spencer J, Isaacson PG, Diss TC, MacDonald TT. Expression of disulphide linked and non-disulphide linked forms of the T cell receptor gamma/delta heterodimer in human intestinal intraepithelial lymphocytes. Eur J Immunol 1989;9:1335-8.

8. Husband AJ, Gowans JL. The origin and antigen-dependent distribution of IgA-containing cells in the intestine. J Exp Med 1978;148:1146-60.

9. Clarke CJ, Wilson AD, Williams NA, Stokes CR. Mucosal priming of T-lymphocyte responses to fed antigens using cholera toxin as an adjuvant. Immunology 1991;72:323-8.

10. Cuenod B, Brousse N, Goulet O, et al. Classification of intractable diarrhea in infancy using clinical and immunohistological criteria. Gastroenterology 1990;99:1037-43.

11. Sanderson IR, Phillips AD, Spencer J, Walker-Smith JA. The response of autoimmune enteropathy to cyclosporin A therapy. Gut 1991;32:1314-7.

12. MacDonald TT, Spencer J. Evidence that activated mucosal $T$ cells play a role in the pathogenesis of enteropathy in human small intestine. J Exp Med $1988 ; 167: 1341-9$
13. MacDonald TT. The role of activated T lymphocytes in gastrointestinal disease. Clin Exp Allergy 1990;20:247-52.

14. Monk TJ, Spencer J, Cerf-Bensussan $\mathrm{N}$, MacDonald TT. Activation of mucosal T-cells in situ with anti-CD3 antibody: Phenotype of the activated T cells and their distribution within the mucosal micro-environment. Clin Exp Immunol 1988;74:216-22.

15. MacDonald TT, Weinel A, Spencer J HLA-DR expression in fetal human small intestinal epithelium. Gut 1988;29:1342-8.

16. Choy M-Y, Richman PI, Walker-Smith JA, MacDonald TT. Differential expression of CD25 (interleukin-2 receptor) on lamina propria T cells and macrophages in the intestinal lesions in Crohn's disease and ulcerative colitis. Gut 1990;31:1365-70. 


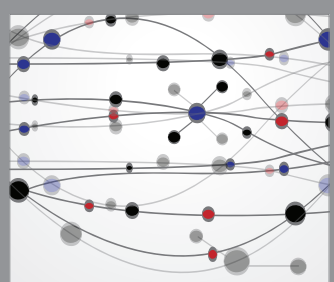

The Scientific World Journal
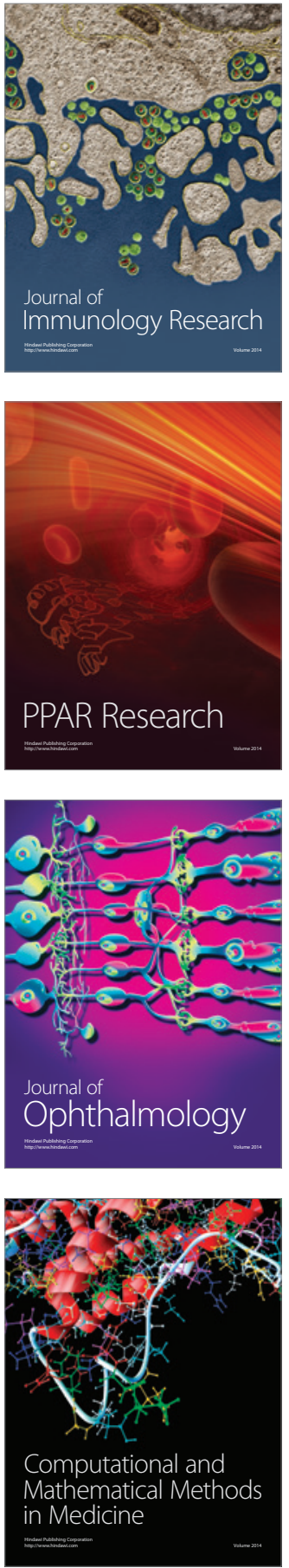

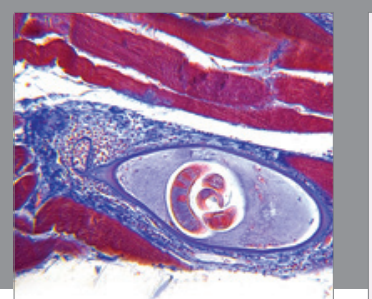

Gastroenterology Research and Practice

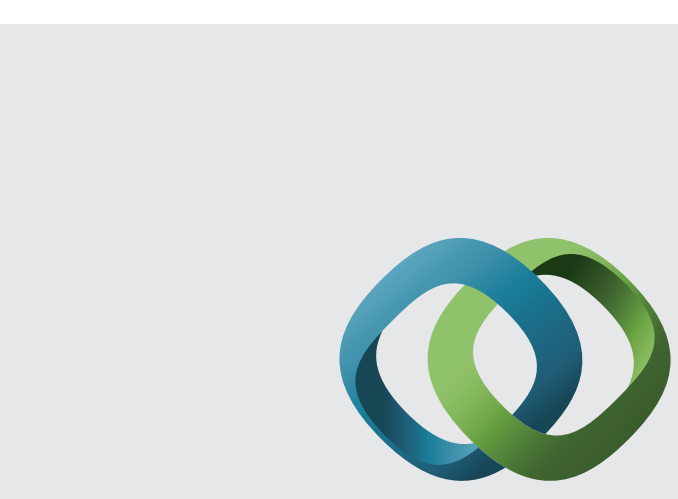

\section{Hindawi}

Submit your manuscripts at

http://www.hindawi.com
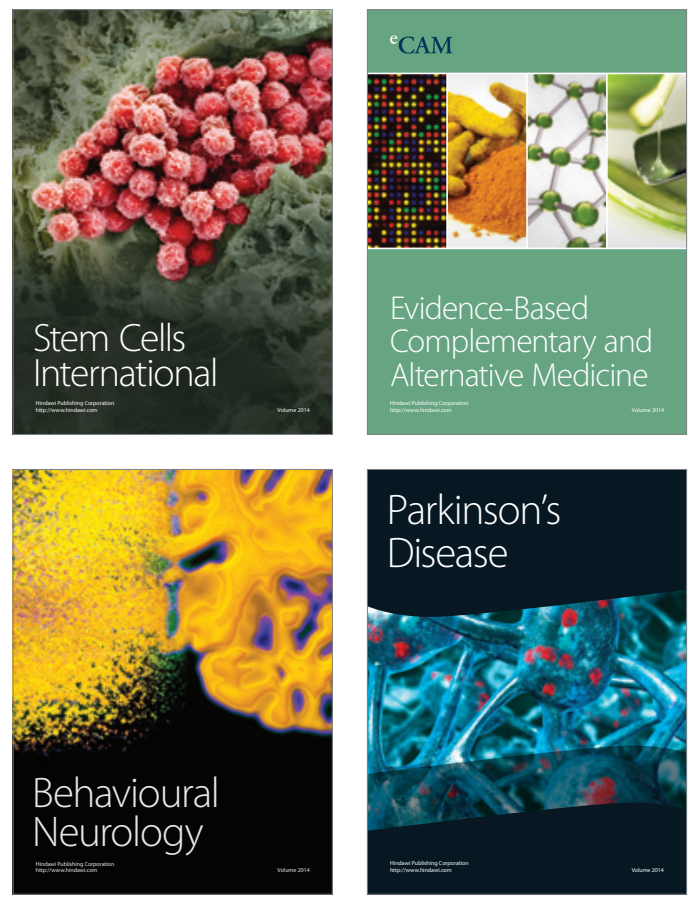
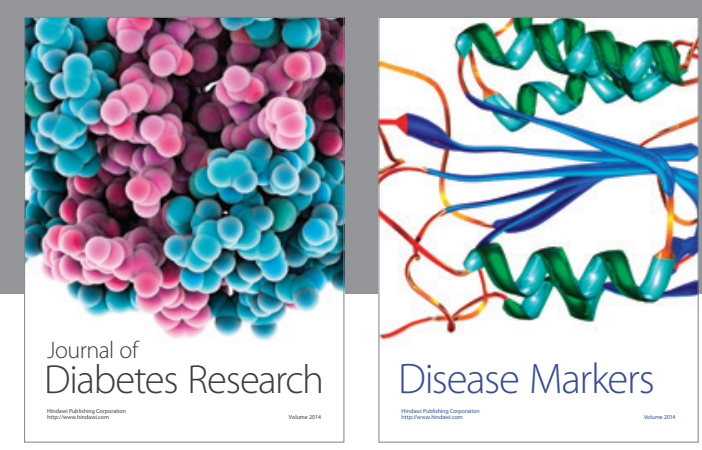

Disease Markers
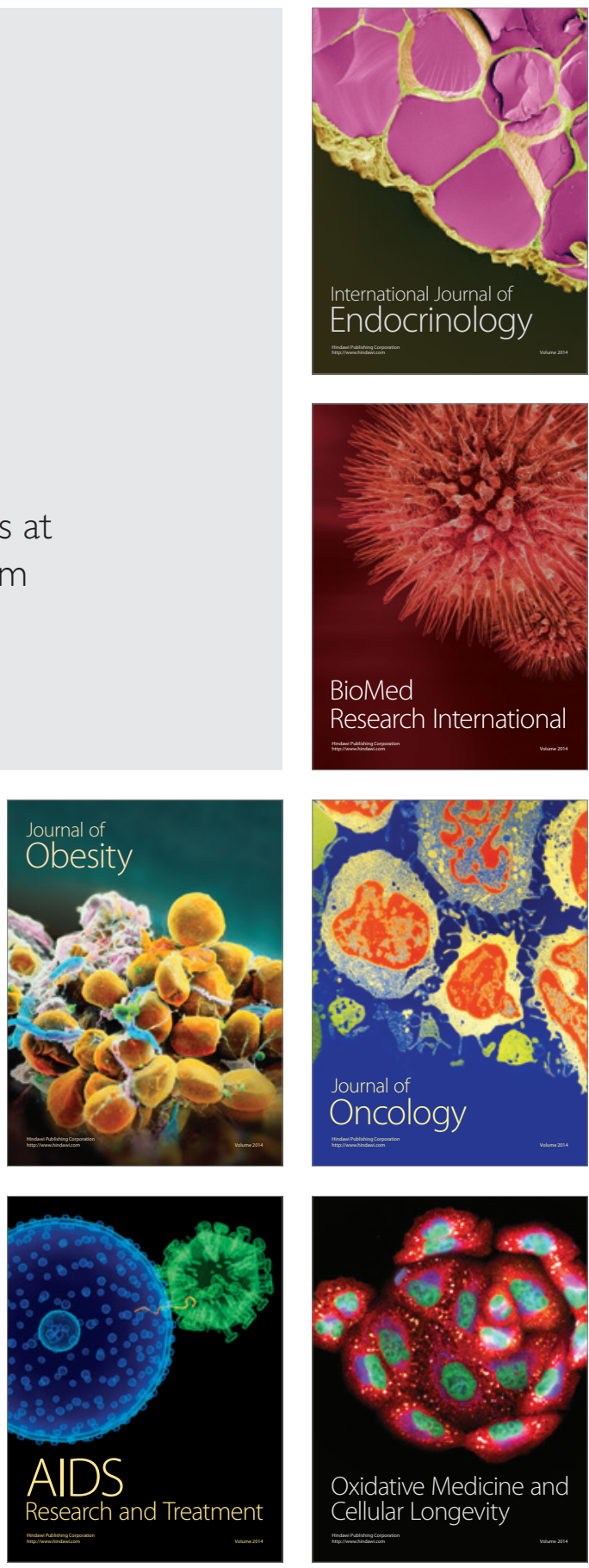